Navarro J, Cardador L, Fernández ÁM, Bellido JM, Coll M (2016) Differences in the relative roles of environment, prey availability and human activity in the spatial distribution of two marine mesopredators living in highly exploited ecosystems. Journal of Biogeography, 43:440450 DOI: $10.1111 /$ jbi.12648

\title{
Differences in the relative roles of environment, prey availability and human activity in the spatial distribution of two marine mesopredators living in highly exploited ecosystems
}

\author{
Joan Navarro ${ }^{1,2^{*}}$, Laura Cardador ${ }^{1}$, Ángel M. Fernández ${ }^{3}$, José M. Bellido ${ }^{3}$ and Marta Coll ${ }^{2,4}$ \\ ${ }^{1}$ Department of Conservation Biology, Estación Biológica de Doñana (EBD-CSIC), Avda. \\ Américo Vespucio s/n, Sevilla 41092, Spain. \\ ${ }^{2}$ Institut de Ciències del Mar (ICM-CSIC), Passeig Marítim de la Barceloneta, 37-49, 08003 \\ Barcelona, Spain. \\ ${ }^{3}$ Instituto Español de Oceanografía, Centro Oceanográfico de Murcia. C/Varadero 1, San Pedro \\ del Pinatar. 30740 Murcia, Spain. \\ ${ }^{4}$ Institut de Recherche pour le Développement, UMR EME 212, Centre de Recherche \\ Halieutique Méditerranéenne et Tropicale, Avenue Jean Monnet BP 171, 34203 Sète cedex, \\ France. \\ *joan@ebd.csic.es
}

\begin{abstract}
Aim Identifying the main factors affecting the spatial distribution of marine predators is essential in order to evaluate their distribution patterns, predict the potential impact of human activities on their populations and design accurate management actions. This information is also valuable from a more general management perspective, since marine predators are often considered indicators of habitat quality. In this context, we aimed to determine the degree to which environmental features, prey availability and human activities interact and influence spatial distribution of two marine mesopredator elasmobranchs, the small-spotted catshark (Scyliorhinus canicula) and the Mediterranean starry ray (Raja asterias), living in a highly human-exploited environment.
\end{abstract}

Location Mediterranean Sea 
Methods With information obtained from an extended experimental survey we investigated the relative importance of environmental variables, prey availability and human activities on the spatial distribution of the abundance, biomass and occurrence rate of these marine mesopredators using deviance partitioning analyses.

Results Our results revealed that environmental variables were the most important factors explaining the spatial distribution of Mediterranean starry ray, whereas small-spotted catshark distribution was also influenced by prey availability and human factors. From a management point of view, these findings suggest that Mediterranean starry ray could be a good candidate as an indicator species of demersal environmental quality. On the other hand, the distribution of the small-spotted catshark, which responds in an interactive and complex way to environment, prey availability and particular human activities, may be misleading as an environmental indicator.

Main conclusions The spatial distribution of elasmobranchs in highly human-impacted marine areas can reflect the interactive and combined effects of multiple factors. To avoid misunderstandings, attention should be paid to statistical procedures allowing the separation of pure and joint contribution of the factors driving the observed spatial patterns.

Keywords: deviance partitioning, elasmobranchs, environmental variables, human stressors, indicator species, marine biodiversity, marine conservation, Mediterranean Sea, Raja asterias, Scyliorhinus canicula

\section{INTRODUCTION}

Identifying and understanding the main factors that affect the spatial distribution of marine biota is important if we are to evaluate the current distribution patterns, predict potential impacts of global change and human activities and design effective management programs (Lasram et al., 2010; Albouy et al., 2012; Morfin et al., 2012). In comparison with other well-studied marine organisms such as seabirds (Fauchald, 2009; Grémillet \& Boulinier, 2009), marine mammals (Jaquet, 1996; Harwood, 2001), marine turtles (Hamann et al., 2010) and other important economic marine species (Bigelow et al., 2002; Katsanevakis et al., 2009), information about the factors that determine the spatial distribution of elasmobranches is relatively scarce (Pennino et al., 2013; Schlaff et al., 2014; Lauria et al., 2015). However, their life-history characteristics such as low fecundity, slow growth and late reproductive maturity make them very vulnerable to ecosystem perturbations. They are predators at or near the top of marine food chain and can play important roles in marine ecosystems (Bascompte et al., 2005; Dulvy et al., 2014). 
Therefore, the depletion or removal of these organisms can affect the structure and function of marine ecosystems, inducing changes at the community level due to selective removal of predators or prey species, competitors and consequent species replacements (Baum \& Worm, 2009; Pennino et al., 2013).

In the Mediterranean Sea, an important hotspot for this group of marine organisms (Dulvy et al., 2014), many species have declined as a consequence of the degradation and loss of habitats or due to the direct impacts of fishing (Ferretti et al., 2008; Coll et al., 2012, 2013, 2015). In fact, around $41 \%$ of the Mediterranean elasmobranchs are considered threatened (classified as 'Critically Endangered', 'Endangered', or 'Vulnerable') and close to 33\% are considered 'Data Deficient' (no reliable biological and ecological information is available for their status assessment) by the regional assessment of the International Union for the Conservation of Nature (Abdul Malak et al., 2011). To counteract the impacts of elasmobranch depletions, in 2009 the European Commission adopted the first Action Plan for the conservation and management of elasmobranchs, with the aim of rebuilding their stocks under threat (European Commision, 2009). This plan also considers the implementation of management actions such as marine spatial planning to protect priority habitats, the reduction of by-catch, and the study of current and expected impacts, with a view to preparing efficient strategies for the preservation of marine biodiversity (Katsanevakis et al., 2009). A solid knowledge of the spatial distribution of marine biota is necessary to achieve these objectives and conduct efficient conservation programs (Coll et al., 2014).

Hitherto, studies assessing the main factors explaining spatial distributions of marine organisms have commonly focused on the effect of environmental variables related to the habitat and prey availability (Torres et al., 2006; Lasram et al., 2010; Pennino et al., 2013). However, in marine ecosystems it is well known that, beyond environmental variables, human activities such as fisheries, pollution or habitat degradation also affect marine organisms, driving changes in their abundance and distribution (Worm et al., 2006; Coll et al., 2012). Despite its importance, few studies have considered the relative contribution of human activities and environmental factors in controlling the distribution of elasmobranchs (Mackinson et al., 2009; Stelzenmüller et al., 2010; Afán et al., 2014; Navarro et al., 2015). This is the case for the Mediterranean Sea, an area heavily impacted by anthropogenic environmental degradation (Coll et al., 2012).

The aim of the present study was to evaluate the relative influence of environmental features, prey availability and human impacts on the spatial distribution of two marine mesopredator elasmobranchs, the small-spotted catshark Scyliorhinus canicula (Linnaeus, 1758) and the Mediterranean starry ray Raja asterias (Delaroche, 1809), in the Western Mediterranean Sea. 
These are two of the few demersal elasmobranchs still widely present in human-impacted areas of the Western Mediterranean Sea (Gouraguine et al., 2011; Coll et al., 2013) and they offer an unequalled opportunity to assess the main factors explaining the spatial distribution of elasmobranchs. We investigated the relative importance of environmental variables, human activities and prey availability on the spatial distribution of the abundance, biomass and occurrence rate of these two species in the area using deviance partitioning analyses (Borcard et al., 1992).

\section{MATERIALS AND METHODS}

\section{Study area}

The study area comprises the Iberian continental shelf and upper slope (up to $800 \mathrm{~m}$ depth) of the Western Mediterranean area, from the Cap de Creus in the north to the Cabo de Palos in the south (Fig. 1). The study area has a latitudinal gradient in both topographic and hydrographic features (Estrada, 1996). The continental shelf broadens in the south and is widest around the Ebro Delta (Fig. 1). This area is particularly productive due to a combined effect of the LiguroProvençal-Catalan current and the runoff from the Ebro River (Estrada, 1996). In the northern area, the continental shelf is narrower, with the Liguro-Provençal-Catalan current flowing south-westwards along the continental slope. The area, particularly the area surrounding the Ebro Delta (Fig. 1), is one of the most important fishing grounds in the Mediterranean Sea, with a large fishing fleet operating in the region (Papaconstantinou \& Farrugio, 2000). Similar to other coastal areas of the Mediterranean Sea, other human threats related to coastal impacts, marine pollution, aquaculture activities and the presence of invasive species are also important (Coll et al., 2012).

\section{Study species}

The small-spotted catshark is one of the most abundant demersal sharks of the Mediterranean Sea and of some parts of the North Atlantic (distributed from 100 to $1500 \mathrm{~m}$ depth; Sion et al., 2007; Gouraguine et al., 2011). Although this species shows an opportunistic feeding behaviour, in the Western Mediterranean it mainly preys on crustaceans and fishes (Valls et al., 2011). The Mediterranean starry ray is a medium-size skate endemic to the Mediterranean Sea (Whitehead et al., 1984). This ray inhabits demersal shallow waters mostly found at a depth of 100-200 m. Its feeds preferentially on crustaceans, although small proportions of fishes and cephalopods can be found in stomach contents (Coll et al., 2013; Navarro et al., 2013). 


\section{Survey design and data used}

The data used in the present study were obtained from the EU-funded Mediterranean Trawl Survey (MEDITS) developed between the years 2002-2012 in the Western Mediterranean (Fig. 1). MEDITS surveys were carried out during the early summer period (May-July) and included standardized sampling with a bottom-trawl (60 minutes of duration) at predefined stations over the coastal and continental shelf areas and the upper slopes from 10 to $800 \mathrm{~m}$ depth (MEDITS protocol; Bertrand et al., 2002). Sampling stations were placed randomly through the study area at the beginning of the project and in all subsequent years sampling was performed in similar locations. The MEDITS protocol uses a codent mesh size of $10 \mathrm{~mm}$ (stretched mesh) and the minimum size of individuals captured measured $2.5 \mathrm{~cm}$. The location of each sampling station was incorporated into a Geographic Information System (GIS) using the world projection WGS European 1984 in a grid of $0.1^{\circ}$ resolution covering the whole study area (the same resolution as the environmental and human variables, see below). A total of 169 cells of this grid were surveyed (average of $70 \pm 8$ cells sampled each year; see Fig. 1 for the location of the cells of $0.1^{\circ}$ resolution sampled). For each cell we calculated the abundance (average of the number of individuals per $\mathrm{km}^{2}$ across all sampling years) and biomass (average of the $\mathrm{kg}$ per $\mathrm{km}^{2}$ across all sampling years) and the occurrence rate (number of years the species was detected/number of years the grid was sampled) of small-spotted catshark and Mediterranean starry ray. We considered the average abundance and biomass across all sampling years in each cell for subsequent analyses because neither the abundance nor the biomass of either species differed between years when using two-way ANOVA tests considering the factors year, cell and the interaction between both factors ( $P$ ranged $0.45-0.91$ for years; and for the interaction year $\times$ cell $P$ ranged $0.06-0.90$ ). Prior to applying ANOVA tests, abundance and biomass data were log-transformed and checked for normality and heteroscedasticity.

\section{Environment, prey availability and human variables}

Environmental variables included (1) chlorophyll- $a$ concentration $\left(\mathrm{CHL}, \mathrm{mg} \cdot \mathrm{C} \cdot \mathrm{m}^{-3}\right)$, (2) sea surface temperature (SST, $\left.{ }^{\circ} \mathrm{C}\right)$, (3) depth (DEPTH, m), (4) dissolved oxygen (DO, $\mathrm{ml} \cdot \mathrm{l}^{-1}$ ), and (5) salinity (PSS) (see Fig. S1 in Appendix S1). SST and CHL were obtained from the Aqua MODIS sensor (http://oceancolor.gsfc.nasa.gov; accessed $1^{\text {st }}$ June 2015) and were extracted from the seasonal average estimates corresponding to the MEDITS survey period (spring) for 2002-2012. Average values were calculated for modelling since SST and CHL were highly correlated among years (Pearson correlation coefficients ranged 0.81-0.94 for SST and 0.640.96 for CHL; all P-values<0.001). DO and PSS were compiled from the Bio-Oracle Project website (Bio-Oracle Project; www.oracle.ugent.be; ; accessed $1^{\text {st }}$ June 2015; Tyberghein et al., 
2012), where they are already available as average composites. The depth variable (DEPTH) was obtained from the ETOPO website (www.ngdc.noaa.gov/mgg/global/global.htm; accessed $1^{\text {st }}$ June 2015).

Prey availability for each species was calculated as the mean abundance (ind $\cdot \mathrm{km}^{-2}$ ) of their potential prey species within $0.1^{\circ}$-grid cells (see list of the potential prey species in Table S1 in Appendix S2; Valls et al., 2011; Coll et al., 2013; Navarro et al., 2013). This information was also obtained from the MEDITS surveys between 2002 and 2012. For these analyses, we grouped the potential prey species into three taxonomic groups (cephalopods, crustaceans and fish; see Fig. S2 in Appendix S1).

As human variables, we used (1) fishing activity and (2) coastal-based impacts (see Fig. S1 in Appendix S1). The fishing activity variable describes the relative position of each grid cell of the study area within the spatial distribution of all fishing harbours, taking into account total fishing landings per harbour each year (Afán et al., 2014; Navarro et al., 2015). Specifically, fishing activity in each grid cell $i\left(F_{i}\right)$ was assessed using a modified version of an isolation function (Moilanen \& Hanski, 1998), with $F_{i}=\sum \exp \left(-\alpha \cdot d_{i j}\right) \cdot P_{j}$, where $\mathrm{d}_{\mathrm{ij}}$ is the linear distance from grid cell $i$ to each harbour $j$ in the study area, $P_{j}$ is the number of total fish landings (tons, $10^{3} \mathrm{~kg}$ ) in harbour $j$ and $\alpha$ is a measure of the influence of fishing vessels, set so that the value of $\exp \left(-\alpha \cdot d_{i j}\right)$ was spread along a $0-1$ gradient, becoming close to zero when the distance was higher than $50 \mathrm{~km}$. We considered $50 \mathrm{~km}$ as the maximum distance reached for the fishing vessels from their harbour based on expert knowledge (Navarro et al., 2015). The distribution of harbours in the study area and information on annual landings were obtained from different official sources (fishing landing sources: www.agricultura.gva.es, http://www.carm.es; accessed $1^{\text {st }}$ June 2015; Fisheries department of the Catalonia Government catch statistics 1986-2012; fishing landings in each port in Table S2 in Appendix S2). Fishing activity was calculated annually. However, average values were calculated for modelling since fishing activity values were highly correlated among years (Pearson correlation coefficients ranged $0.97-0.99$, all $P$ values $<0.001$ ). Although, limited information for the whole study area, prevented using direct spatial fishing data for fishing activity calculation, our fishing activity variable was significantly correlated (Pearson correlation coefficient $=0.64 ; P<0.001$ ) with fishing effort (hours of fishing activity $\mathrm{km}^{-1}$ ) obtained with vessel monitoring system data in the north of the study area between 2005 and 2014 (J.B. Company and J.A. García, unpublished data; see Fig. S3 in Appendix S1). Thus, we believe that this variable could be a reasonable surrogate to explain current distribution patterns of fishing effort.

The coastal-based impact variable is a combined measure of inorganic and organic coastal pollution, nutrient runoff, aquaculture activities and the presence of invasive species in the study 
area (see Coll et al., 2012; Navarro et al., 2015 for more details on these variables). All variables were obtained at $0.1^{\circ}$ resolution.

\section{Analytical procedures}

We used deviance partitioning to analyse the importance of the different predictor sets considered (environment, human and prey availability variables) for the abundance, biomass and occurrence rate of each elasmobranch species (Borcard et al., 1992). Deviance partitioning procedures allows separation of the pure effect of each predictor set from the joint effects that cannot be attributed to only one predictor set due to spatial collinearity (Borcard et al., 1992; Heikkinen et al., 2004; Cardador et al., 2011). This method entails the calculation of incremental improvement in model fit due to the inclusion of a predictor set in every possible model incorporating that predictor set. For these calculations, we constructed (partial) generalized linear models (GLMs) containing different combinations of the predictor sets, namely (1) environment, (2) prey availability, (3) human, (4) environment + prey availability, (5) human + prey availability, (6) environment + human, and (7) environment + human+ prey availability. Both the linear and quadratic forms of each environmental, human activity and prey availability variables were included in models to test for potential parabolic trends (i.e., higher and lower values of a variable imply an increase/decrease in abundance or occurrence rate compared with intermediate values). Note that testing the quadratic form of these variables implies the inclusion of both the variable and its squared term in a model.

We use a multimodel inference approach for model selection. Multimodel inference implies the calculation of the set of models containing all possible combinations of the considered variables (also its linear and quadratic forms). For each model a probability of being the best model according to Bayesian information criteria (BIC), which strongly penalizes for the number of parameters in models (Burnham \& Anderson, 2004), was calculated. Final models were then calculated as averaged values of models receiving higher support (i.e. those with the 95\% cumulative probability of including the best model) (Burnham \& Anderson, 2004; Whittingham et al., 2005). Model-averaged parameter estimates and their standard errors were calculated, along with variable weights, which indicate the relative importance of each variable in the average model. In order to evaluate the significance of each variable in the average model, we generated a random predictor non-correlated with the response variable, from a uniform distribution between 0 and 1 . This random predictor was included in the model selection process along with the rest of variables. The model selection procedure was repeated 100 times so that only variables whose weight was above the $95 \%$ confidence interval for the average weight of the random predictor were considered significant (for a similar 
approximation, see Whittingham et al., 2005). Non-significant variables in single environment, human or prey availability models were removed and not included in more complex models. . Multimodel inference was implemented in R software by the functions 'dredge' and 'model.avg' from the 'MuMIm' library. We fitted a normal error distribution and an identitylink function for abundance (log transformation) and biomass (log transformation) and a binomial error distribution and logit-link function for occurrence rate. Estimated contributions of different predictor sets were based on $R^{2}$ for abundance and biomass and pseudo- $R^{2}$ for occurrence rate (Heinzl \& Mittlböck, 2003). Other statistical analysis was performed in IBM SPSS 20 (IBM SPSS, Inc, Chicago, IL).

\section{RESULTS}

In total, 117 of 169 sampled $0.1^{\circ}$-grid cells were occupied at least once during the study period by one of the study species and 32 by both species. The small-spotted catshark showed higher (1-2 order of magnitude) abundance, biomass and occurrence rates than the Mediterranean starry ray across the study area (mean \pm standard deviation; small-spotted catshark, abundance $=60.19 \pm 195.27$ ind $\cdot \mathrm{km}^{2}$, biomass $=363.59 \pm 954.41 \mathrm{~kg} \cdot \mathrm{km}^{2}$, occurrence rate $=0.46 \pm 0.42$; Mediterranean starry ray, abundance $=3.21 \pm 15.31 \mathrm{ind} \cdot \mathrm{km}^{2}$, biomass $=4.26 \pm 12.14 \mathrm{~kg} \cdot \mathrm{km}^{2}$, occurrence rate $=0.09 \pm 0.20$ ) and total individuals captured (391 small-spotted catsharks and 89 Mediterranean starry rays). The spatial distribution of the two species also was different. The small-spotted catshark was widely distributed, being detected in $63 \%$ of the sampled grid cells, and showed higher abundances, biomasses and occurrence rates in the north and south regions of the sampling area (Fig. 2). In contrast, the Mediterranean starry ray was detected at least once in only $24 \%$ of the sampling grid cells and showed higher abundances, biomasses and occurrence rates in the waters close to the Ebro Delta and in the south of the study area (Fig. 3).

\section{Response to environment, prey availability and human activity variables}

Among environmental variables both the linear and squared term of depth received strong support in abundance and occurrence rate models of small-spotted catshark (Table 1; Table S3 in Appendix S2). Thus, the abundance and occurrence rate of small-spotted catshark increased with intermediate values of depth (negative values of the squared term, Table 1; Figs S4 \& S6 in Appendix S3). In contrast, the abundance and biomass of Mediterranean starry ray slightly increased linearly with depth (Table 1; Figs S4 \& S5 in Appendix S3). Chlorophyll and dissolved oxygen concentrations were only supported as important variables for Mediterranean 
starry ray. In particular, chlorophyll showed a positive relationship with abundance and biomass and dissolved oxygen a negative relationship with occurrence rate (Table 1; Figs S4-S6 in Appendix S3). In contrast, high support was obtained for salinity for both species, with both showing a similar response. The abundance, biomass and occurrence rate of small-spotted catshark and Mediterranean starry ray increased (positive values of the squared term) in a curvilinear fashion with low and high values of salinity (Table 1; Figs S4-S6 in Appendix S3, but see exception for occurrence rate of Mediterranean starry ray).

In relation to the prey availability variables, the abundance, biomass and occurrence rate of small-spotted catshark and Mediterranean starry ray showed overall a positive linear response to the abundance of finfish (Table 1; Figs S4-S6 in Appendix S3). Moreover, intermediate cephalopod abundances resulted in higher abundance and occurrence rate of small-spotted catshark (Table 1; Figs S4 \& S6 in Appendix S3).

Among human variables, fishing activity and coastal-based impacts had a clear effect on the abundance, biomass and occurrence rate of small-spotted catshark (Table 1; Figs S4-S6 in Appendix S3), suggesting that small-spotted catsharks decreased linearly or in a more curvilinear fashion with fishing activity and coastal-based impacts (Table 1; Figs S4-S6 in Appendix S3). The human variables were poor at explaining the distribution of the abundance, biomass or occurrence of the Mediterranean starry ray (Table 1).

\section{Relative importance of environment, prey availability and human factors}

Overall, the amount of variation in the abundance, biomass and occurrence rate captured by all environment, prey availability and human factors was higher for small-spotted catshark $(61 \%$, $59 \%$ and $87 \%$, respectively) than for Mediterranean starry ray $(28 \%, 25 \%$ and $47 \%$, respectively).

According to deviance partitioning, the pure effect of environmental factors accounted for a high individual fraction of the abundance, biomass and occurrence rate of Mediterranean starry ray (Fig. 4). In contrast, for small-spotted catshark the environmental factors were less important in explaining spatial patterns (Fig. 4). The pure effect of prey availability accounted for a larger fraction of the variability of the abundance, biomass and occurrence rate for smallspotted catshark (Fig. 4). The pure effect of human activity had only an apparent effect on the abundance, biomass and occurrence rate of small-spotted catshark, whereas for Mediterranean starry ray the pure effect of human activity was not important (Fig. 4). Interestingly, the joint effect (i.e., the effect that cannot be unambiguously attributed to one predictor set or another due to spatial autocorrelation) of all the groups of predictors included in the analysis explained the 
major part of the variability in the abundance and occurrence rate of small-spotted catshark (Fig. $4)$.

\section{DISCUSSION}

The present study revealed the contrasting importance of environment, prey availability and human activity predictors in the spatial ecology of two mesopredator elasmobranchs, the smallspotted catshark and the Mediterranean starry ray, in the Western Mediterranean sea, a highly human-impacted area (Coll et al., 2013; Navarro et al., 2015).

Although environmental variables have been described as important factors influencing the spatial distribution of elasmobranchs (Maravelias et al., 2012; Pennino et al., 2013; Schlaff et al., 2014; Lauria et al. 2015), we found that the pure effect of environmental variables analysed was clearly more important for Mediterranean starry ray than for small-spotted catshark, likely associated with the more specific habitat-requirements of the Mediterranean starry ray. Specifically, we found that dissolved oxygen concentration, salinity and chlorophyll-a have a clear effect on the spatial abundance, biomass and occurrence rate of Mediterranean starry ray. Dissolved oxygen and salinity concentrations, although not frequently used in elasmobranch research, have been described as important factors influencing the spatial distribution of some elasmobranch species (Harris et al., 2009; Espinoza et al., 2011; Bernal et al., 2012; Martin et al., 2012; Speers-Roesch et al., 2012; Navarro et al., 2015). In the case of the Mediterranean starry ray, our results suggest that the occurrence rate of this species responds negatively to the dissolved oxygen values. This situation may allow Mediterranean starry ray to exploit resources present in hypoxic environments that are not accessible to other competing marine predators (Jorgensen et al., 2009; Craig et al., 2010). In the case of salinity, although no specific physiological studies have been conducted with Mediterranean starry ray, our results suggest that this species (and also the small-spotted catshark) apparently avoid waters with medium salinity concentrations. Chlorophyll- $a$ concentration, a proxy of marine productivity, was also an important variable describing the spatial distribution of the Mediterranean starry ray indicating that this species is present in more productive waters of the study area (Kendall \& Haedrich, 2006).

In addition to environmental variables, the availability of trophic resources has also been described as an important factor affecting the distribution of marine predators (Torres et al., 2006; Fauchald, 2009). In our case, prey availability affected the three spatial descriptor metrics of small-spotted catshark and the occurrence rate of the Mediterranean starry ray. In the case of small-spotted catshark we found an apparent correspondence between its generalist trophic 
habits (Valls et al., 2011) and the fact that the abundance of finfish and cephalopods explained its spatial distribution. Based on previous studies, we expected crustacean abundance to be an important variable explaining the spatial distribution of Mediterranean starry ray, which is a predator of marine crustaceans (Navarro et al., 2013). A potential explanation for the low importance of crustaceans for the distribution of this species could be that we considered all crustacean species as a proxy of crustacean availability for analyses, due to data limitations. This may have obscured the relative abundance of particular crustacean species such as the angular crab Goneplax rhomboides or harbour crab Liocarcinus depurator, described as the main prey of the Mediterranean starry ray in the Western Mediterranean (Navarro et al., 2013).

In comparison to environmental variables, the effect of human activity on spatial distribution of elasmobranchs has been comparatively less well investigated (Mackinson et al., 2009; Stelzenmüller et al., 2010; Navarro et al., 2015). Although we expected that human activity would affect both species (Coll et al., 2013), we found that human activities only had an effect on the spatial distribution of small-spotted catshark when controlling for potential effect of environment and prey availability. In particular, we found that fishing activity negatively affect the abundance, biomass and occurrence rate of this species. However, decreases, particularly in the case of occurrence rate, are mostly curvilinear; so that negative effects become steeper at higher fishing activity values (see Fig. S5 in Appendix S3). This result could be related with the reduction of potential competitors in areas with low to intermediate fishing activity or to the capacity of the species to exploit resources provided by fisheries, such as fish discards (Savina et al., 2013; Revill et al., 2005). In a previous study in the Gulf of Lions (NW Mediterranean Sea) the small-spotted catshark was the last predator to disappear from high intensity trawling areas (Aldebert, 1997), which also suggests that the species was less affected by human impacts than other elasmobranch species. For the Mediterranean starry ray, although previous research highlighted a clearly negative effect of fishing activity on its biomass in the Southern Catalan Sea (Coll et al., 2013), here we found that human parameters were not essential to explain the abundance, biomass and occurrence rate of this species. This result could be explained by the fact that the data from the present study are from a larger area (the entire Western Mediterranean) and the previous study was conducted in the waters close to the Ebro Delta (Fig. 1), an area highly impacted by trawling activity, a type of fishing that impacts significantly on the abundance of this species (Coll et al., 2013; Navarro et al., 2015). However, these results could also suggest that the impacts of human activities on the populations of this ray are indirect and can be complex, interacting with other biotic and abiotic factors.

While understanding the response of species to particular variables is interesting from an ecological point of view, quantifying the way these multiple factors interact and combine 
spatially to shape distributions may be even more informative from a management point of view. For example, marine predators have been considered in general as good indicators of habitat quality (Furness \& Camphuysen, 1997; Metcheva et al., 2006; Gómez-Salazar et al., 2012). However, useful indicators are expected to respond in a clear way to particular environmental or human impact variables. Here, simultaneous analysis of the effect of different ecological factors (i.e., environment, prey availability and human activity) on spatial abundance, biomass and occurrence rate of elasmobranchs showed that joint responses to different factors may sometimes be more important than pure responses. This is the case for the small-spotted catshark and may be related to the widespread distribution and high abundance of the species in the Western Mediterranean Sea. However, the difficulty in determining which factors ultimately underlie its distribution limits the usefulness of the species as an indicator. In contrast, the abundance and biomass of Mediterranean starry ray is mainly explained by the pure effect of the environment, suggesting that this endemic ray could be used more confidently as an indicator species for habitat quality. Similar studies, allowing the separation of pure and joint effects of potential factors driving species distribution patterns, could contribute to identifying good candidate species as indicators of different factors in the study area. Our results contribute to the current knowledge on the spatial distribution of elasmobranchs in the Mediterranean Sea, advancing the development of more complex spatial analyses (Pennino et al., 2013; Steenbeek et al., 2013; Navarro et al., 2015).

\section{ACKNOWLEDGEMENTS}

Thanks to Joan B. Company and José A. Garcia for providing fishing effort information based on Vessel Monitoring System from the Catalan Sea. JN was partially funded by the European Commission through the Marie Curie Career Integration Grant Fellowships (PCIG10-GA-2011303534, BIOWEB project) and by the ESFRI LifeWatch project. LC was funded by the ESFRI LifeWatch project. MC was also partially supported by BIOWEB and by the Spanish Ramon y Cajal Program (Spanish Ministry of Economy and Competiveness).

\section{REFERENCES}

Abdul Malak, D., Livingstone, S.R., Pollard, D., Polidoro, B.A., Cuttelod, A., Bariche, M., Bilecenoglu, M., Carpenter, K.E., Collette, B.B., Francour, P., Goren, M., Kara, M.H., Massutí, E., Papaconstantinou, C. \& Tunesi, L. (2011) Overview of the conservation status of the marine fishes of the Mediterranean Sea. UICN.Gland, Switzerland and Malaga, Spain.

Afán, I., Navarro, J., Cardador, L., Ramírez, F., Kato, A., Rodríguez, B., Ropert-Coudert, Y. \& Forero, M.G. (2014) Foraging movements and habitat niche of two closely-related seabirds breeding in sympatry. Marine Biology, 161, 657-668. 
Albouy, C., Guilhaumon, F., Araújo, M.B., Mouillot, D. \& Leprieur, F. (2012) Combining projected changes in species richness and composition reveals climate change impacts on coastal Mediterranean fish assemblages. Global Change Biology, 18, 2995-3003.

Aldebert, Y. (1997) Demersal resources of the Gulf of Lions (NW Mediterranean). Impact of exploitation on fish diversity. Vie et Milieu, 47, 275-284.

Bascompte, J., Melián, C.J. \& Sala, E. (2005) Interaction strength combinations and the overfishing of a marine food web. Proceedings of the National Academy of Sciences USA, 102, 5443-5447.

Baum, J.K. \& Worm, B. (2009) Cascading top-down effects of changing oceanic predator abundances. Journal of Animal Ecology, 78, 699-714.

Bernal, D., Carlson, J.K., Goldman, K.J. \& Lowe, C.G. (2012) Energetics, metabolism, and endothermy in sharks and rays. Biology of sharks and their relatives (ed. by J. Carrier, J. Musick and M. Heithaus), pp 211-237. CRC Press, Boca Raton.

Bertrand, J.A., Gil de Sola, L., Papaconstantinou, C., Relini, G. \& Souplet, A. (2002) The general specifications of the MEDITS surveys. Scientia Marina, 66, 9-17.

Bigelow, K.A., Hampton, J. \& Miyabe, N. (2002) Application of a habitat-based model to estimate effective longline fishing effort and relative abundance of Pacific bigeye tuna (Thunnus obesus). Fisheries Oceanography, 11, 143-155.

Borcard, D., Legendre, P. \& Drapeau, P. (1992) Partialling out the spatial component of ecological variation. Ecology, 73, 1045 -1055.

Burnham, K.P. \& Anderson, D.R. (2004) Multimodel Inference: Understanding AIC and BIC in Model Selection. Sociological Methods \& Research, 33, 261-304.

Cardador, L., Carrete, M. \& Mañosa, S. (2011) Can intensive agricultural landscapes favour some raptor species? The Marsh harrier in north-eastern Spain. Animal Conservation, 14, 382-390.

Coll, M., Navarro, J. \& Palomera, I. (2013) Ecological role, fishing impact, and management options for the recovery of a Mediterranean endemic skate by means of food web models. Biological Conservation, 157, 108-120.

Coll, M., Piroddi, C., Albouy, C., Ben Rais Lasram, F., Cheung, W.W.L., Christensen, V., Karpouzi, V.S., Guilhaumon, F., Mouillot, D., Paleczny, M., Palomares, M.L., Steenbeek, J., Trujillo, P., Watson, R. \& Pauly, D. (2012) The Mediterranean Sea under siege: spatial overlap between marine biodiversity, cumulative threats and marine reserves. Global Ecology and Biogeography, 21, 465480 .

Coll, M., Steenbeek, J., Ben Rais Lasram, F., Mouillot, D. \& Cury, P. (2015) “Low-hanging fruit” for conservation of marine vertebrate species at risk in the Mediterranean Sea. Global Ecology and Biogeography, 24, 226-239.

Craig, J.K., Gillikin, P.C., Magelnicki, M.A. \& May, L.N. (2010) Habitat use of cownose rays (Rhinoptera bonasus) in a highly productive, hypoxic continental shelf ecosystem. Fisheries Oceanography, 19, 301-317.

Dulvy, N.K., Fowler, S.L., Musick, J.A., et al. (2014) Extinction risk and conservation of the world's sharks and rays. eLife, 3, e00590. 
Espinoza, M., Farrugia, T.J. \& Lowe, C.G. (2011) Habitat use, movements and site fidelity of the gray smooth-hound shark (Mustelus californicus Gill 1863) in a newly restored southern California estuary. Journal of Experimental Marine Biology and Ecology, 401, 63-74.

Estrada, M. (1996) Primary production in the northwestern Mediterranean. Scientia Marina, 60, 55-64.

European Commission (2009) Communication from the Commission to the European Parliament and the Council on a European Community Action Plan for the Conservation and Management of Sharks. COM 40.40 pp. Available at http://eurlex.europa.eu/LexUriServ/LexUriServ.do?uri=COM:2009:0040:FIN:EN:PDF(accessed 1 June 2015).

Fauchald, P. (2009) Spatial interaction between seabirds and prey: review and synthesis. Marine Ecology Progress Series, 391, 139-151.

Ferretti, F., Myers, R.A., Serena, F. \& Lotze, H.K. (2008) Loss of large predatory sharks from the Mediterranean Sea. Conservation Biology, 22, 952-64.

Furness, R.W. \& Camphuysen, K.J. (1997) Seabirds as monitors of the marine environment. ICES Journal of Marine Science, 54, 726-737.

Gómez-Salazar, C., Coll, M. \& Whitehead, H. (2012) River dolphins as indicators of ecosystem degradation in large tropical rivers. Ecological Indicators, 23, 19-26.

Gouraguine, A., Hidalgo, M., Moranta, J., Bailey, D.M., Ordines, F., Guijarro, B., Valls, M., Barberá, C. \& de Mesa, A. (2011) Elasmobranch spatial segregation in the western Mediterranean. Scientia Marina, 75, 653-664.

Grémillet, D. \& Boulinier, T. (2009) Spatial ecology and conservation of seabirds facing global climate change: a review. Marine Ecology Progress Series, 391, 121-137.

Hamann, M., Godfrey, M.H., Seminoff, J.A., et al. (2010) Global research priorities for sea turtles: informing management and conservation in the 21st century. Endangered Species Research, 11, 245269.

Harris, M.P., Daunt, F., Newell, M., Phillips, R.A. \& Wanless, S. (2009) Wintering areas of adult Atlantic puffins Fratercula arctica from a North Sea colony as revealed by geolocation technology. Marine Biology, 157, 827-836.

Harwood, J. (2001) Marine mammals and their environment in the twenty-first century. Journal of Mammalogy, 82, 630-640.

Heikkinen, R.K., Luoto, M., Virkkala, R. \& Rainio, K. (2004) Effects of habitat cover, landscape structure and spatial variables on the abundance of birds in an agricultural-forest mosaic. Journal of Applied Ecology, 41, 824-835.

Heinzl, H. \& Mittlböck, M. (2003) Pseudo R-squared measures for Poisson regression models with overor underdispersion. Computational Statistics \& Data Analysis, 44, 253-271.

Jaquet, N. (1996) How spatial and temporal scales influence understanding of Sperm Whale distribution: a review. Mammal Review, 26, 51-65.

Jorgensen, S.J., Klimley, A.P. \& Muhlia-Melo, A.F. (2009) Scalloped hammerhead shark Sphyrna lewini, utilizes deep-water, hypoxic zone in the Gulf of California. Journal of Fish Biology, 74, 1682-7. 
Katsanevakis, S., Maravelias, C.D., Damalas, D., Karageorgis, A.P., Tsitsika, E.V., Anagnostou, C. \& Papaconstantinou, C. (2009) Spatiotemporal distribution and habitat use of commercial demersal species in the eastern Mediterranean Sea. Fisheries Oceanography, 18, 439-457.

Kendall, V.J. \& Haedrich, R.L. (2006) Species richness in Atlantic deep-sea fishes assessed in terms of the mid-domain effect and Rapoport's rule. Deep Sea Research Part I: Oceanographic Research Papers, 53, 506-515.

Lasram, F., Guilhaumon, F., Albouy, C., Somot, S., Thuiller, W. \& Mouillot, D. (2010) The Mediterranean Sea as a "cul-desac" for endemic fishes facing climate change. Global Change Biology, 16, 3233-3245.

Lauria, V., Gristina, M., Attrill, M. J., Fiorentino, F. \& Garofalo, G. (2015) Predictive habitat suitability models to aid conservation of elasmobranch diversity in the central Mediterranean Sea. Scientific Reports, 5, 13245.

Mackinson, S., Daskalov, G., Heymans, J.J., Neira, S., Arancibia, H., Zetina-Rejón, M., Jiang, H., Cheng, H.Q., Coll, M., Arreguin-Sánchez, F., Keeble, K. \& Shannon, L. (2009) Which forcing factors fit? Using ecosystem models to investigate the relative influence of fishing and changes in primary productivity on the dynamics of marine ecosystems. Ecological Modelling, 220, 2972-2987.

Maravelias, C.D., Tserpes, G., Pantazi, M. \& Peristeraki, P. (2012) Habitat selection and temporal abundance fluctuations of demersal cartilaginous species in the Aegean Sea (eastern Mediterranean). PloS ONE, 7, e35474.

Martin, C.S., Vaz, S., Ellis, J.R., Lauria, V., Coppin, F. \& Carpentier, A. (2012) Modelled distributions of ten demersal elasmobranchs of the eastern English Channel in relation to the environment. Journal of Experimental Marine Biology and Ecology, 418-419, 91-103.

Metcheva, R., Yurukova, L., Teodorova, S. \& Nikolova, E. (2006) The penguin feathers as bioindicator of Antarctica environmental state. Science of the Total Environment, 362, 259-265.

Moilanen, A. \& Hanski, I. (1998) Metapopulation dynamics: effects of habitat quality and landscape structure. Ecology, 79, 2503-2515.

Morfin, M., Fromentin, J.M., Jadaud, A. \& Bez, N. (2012) Spatio-temporal patterns of key exploited marine species in the Northwestern Mediterranean Sea. PloS ONE, 7, e37907.

Navarro, J., Coll, M., Cardador, L., Fernández, Á.M. \& Bellido, J.M. (2015) The relative roles of the environment, human activities and spatial factors in the spatial distribution of marine biodiversity in the Western Mediterranean Sea. Progress in Oceanography, 131,126-137.

Navarro, J., Coll, M., Preminger, M. \& Palomera, I. (2013) Feeding ecology and trophic position of a Mediterranean endemic ray: consistency between sexes, maturity stages and seasons. Environmental Biology of Fishes, 96, 1315-1328.

Olaso, I., Velasco, F. \& Pérez, N. (1998) Importance of discarded blue whiting (Micromesistius poutassou) in the diet of lesser spotted dogfish (Scyliorhinus canicula) in the Cantabrian Sea. ICES Journal of Marine Science, 55, 331-341.

Papaconstantinou, C. \& Farrugio, H. (2000) Fisheries in the Mediterranean. Mediterranean Marine Science, 1, 5-18. 
Pennino, M.G., Muñoz, F., Conesa, D., López-Quílez, A. \& Bellido, J.M. (2013) Modeling sensitive elasmobranch habitats. Journal of Sea Research, 83, 209-218.

Revill, A.S., Dulvy, N.K. \& Holst, R. (2005) The survival of discarded lesser-spotted dogfish (Scyliorhinus canicula) in the Western English Channel beam trawl fishery. Fisheries Research, 71, 121-124.

Savina, M., Forrest, R.E., Fulton, E.A. \& Condie, S.A. (2013) Ecological effects of trawling fisheries on the eastern Australian continental shelf: a modelling study. Marine and Freshwater Research, 64, 1068.

Schlaff, A.M., Heupel, M.R. \& Simpfendorfer, C.A. (2014) Influence of environmental factors on shark and ray movement, behaviour and habitat use: a review. Reviews in Fish Biology and Fisheries, 24, 1089-1103.

Sion, L., Bozzano, A., D’Onghia, G., Capezzuto, F. \& Panza, M. (2007) Chondrichthyes species in deep waters of the Mediterranean Sea. Scientia Marina, 68.

Speers-Roesch, B., Richards, J.G., Brauner, C.J., Farrell, A.P., Hickey, A.J.R., Wang, Y.S. \& Renshaw, G.M.C. (2012) Hypoxia tolerance in elasmobranchs. I. Critical oxygen tension as a measure of blood oxygen transport during hypoxia exposure. Journal of Experimental Biology, 215, 93-102.

Steenbeek, J., Coll, M., Gurney, L., Mélin, F., Hoepffner, N., Buszowski, J. \& Christensen, V. (2013) Bridging the gap between ecosystem modeling tools and geographic information systems: Driving a food web model with external spatial-temporal data. Ecological Modelling, 263, 139-151.

Stelzenmüller, V., Lee, J., South, A. \& Rogers, S.I. (2010) Quantifying cumulative impacts of human pressures on the marine environment: a geospatial modelling framework. Marine Ecology Progress Series, 398, 19-32.

Torres, L.G., Heithaus, M.R. \& Delius, B. (2006) Influence of teleost abundance on the distribution and abundance of sharks in Florida Bay, USA. Hydrobiologia, 569, 449-455.

Tyberghein, L., Verbruggen, H., Pauly, K., Troupin, C., Mineur, F. \& De Clerck, O. (2012) BioORACLE: a global environmental dataset for marine species distribution modelling. Global Ecology and Biogeography, 21, 272-281.

Valls, M., Quetglas, A., Ordines, F. \& Moranta, J. (2011) Feeding ecology of demersal elasmobranchs from the shelf and slope off the Balearic Sea (western Mediterranean). Scientia Marina, 75, 633-639.

Whitehead, P.J.P., Bauchot, M.L., Hureau, J.C., Nielsen, J. \& Tortonese, E. (1984) Fishes of the NorthEastern Atlantic and Mediterranean (FNAM). Vol. 1. UNESCO, Paris, France.

Whittingham, M.J., Swetnam, R.D., Wilson, J.D., Chamberlain, D.E. \& Freckleton, R.P. (2005) Habitat selection by yellowhammers Emberiza citrinella on lowland farmland at two spatial scales: implications for conservation management. Journal of Applied Ecology, 42, 270-280.

Worm, B., Barbier, E.B., Beaumont, N., Duffy, J.E., Folke, C., Halpern, B.S., Jackson, J.B.C., Lotze, H.K., Micheli, F., Palumbi, S.R., Sala, E., Selkoe, K.A., Stachowicz, J.J. \& Watson, R. (2006) Impacts of biodiversity loss on ocean ecosystem services. Science, 314, 787-90. 


\section{SUPPORTING INFORMATION (electronic)}

Additional Supporting Information may be found in the online version of this article:

Appendix S1. Supplementary figures: Spatial gradients of environmental variables and human activity (Fig. 1); prey availability in the study area (Fig S2); relationship between fishing activity based on official landings and Vessel Monitoring System data (Fig. S3).

Appendix S2. Supplementary tables: potential prey species (Table S1); location of all fishing harbours and fishing landings in the study area (Table S2); model averaged results (Table S3).

Appendix S3. Partial response curves for predictors retained in final models (Figs S4-6).

\section{BIOSKETCH}

Joan Navarro is a postdoctoral researcher interested in the ecology, behaviour and conservation of marine predators, with special interest in their ecological roles in marine ecosystems, their trophic relationships at the food-web level and the main ecological and evolutionary factors, including natural and human-mediated factors, that modulate their behavioural and community patterns. He works at different levels of ecological complexity (from individuals to communities), with different study models (seabirds, elasmobranchs, finfish and cephalopods) and contrasting biogeographical areas (template, tropical and polar environments).

Author contributions: J.N., M.C. and L.C. designed the analysis; J.M.B. and A.M.F. participated in the long-term fieldwork. J.N. and L.C carried out the statistical modelling with input from M.C. All authors contributed to the manuscript text.

Editor: Gustav Paulay 
Table 1. Model-averaged results for the abundance, biomass and occurrence rate of small-spotted catshark Scyliorhinus canicula and Mediterranean starry ray Raja asterias according to environment, prey availability and human activity variables in the Western Mediterranean Sea. The table indicates the relative importance (i.e., selection probability in the $95 \%$ confidence set of models according to BIC) of each variable for each species and the type of response ("+"= positive; "-"= negative) in multivariate models considering all three groups of variables. In bold variables whose relative importance (weight) was above the $95 \%$ confidence interval for the average weight over 100 replications (provided in brackets) of a random predictor non-correlated with the response variable included in models.

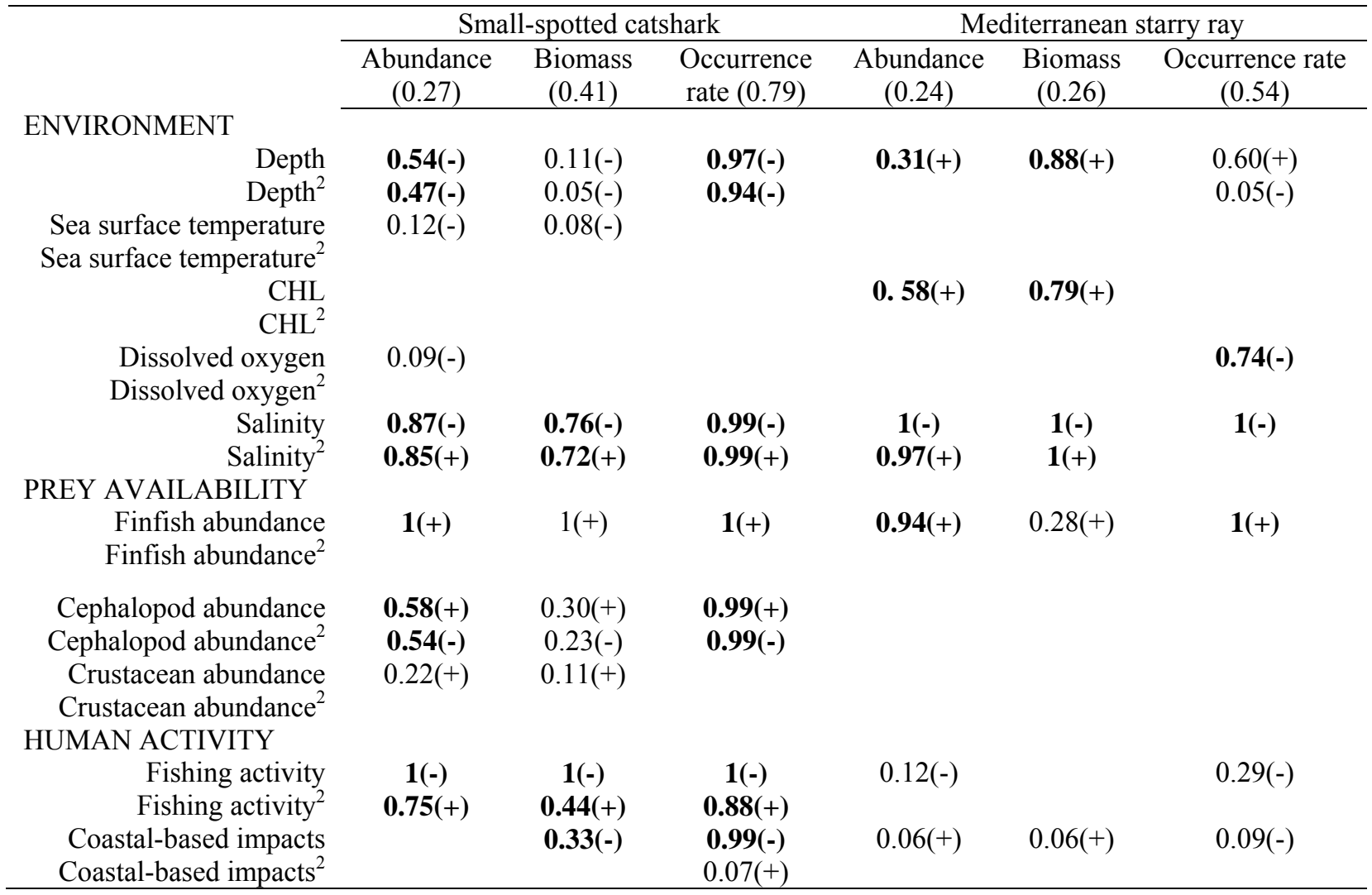


Figure 1. (a) Distribution of the sampled fishing grid in the Western Mediterranean Sea and (b) the geographic position of the study area.

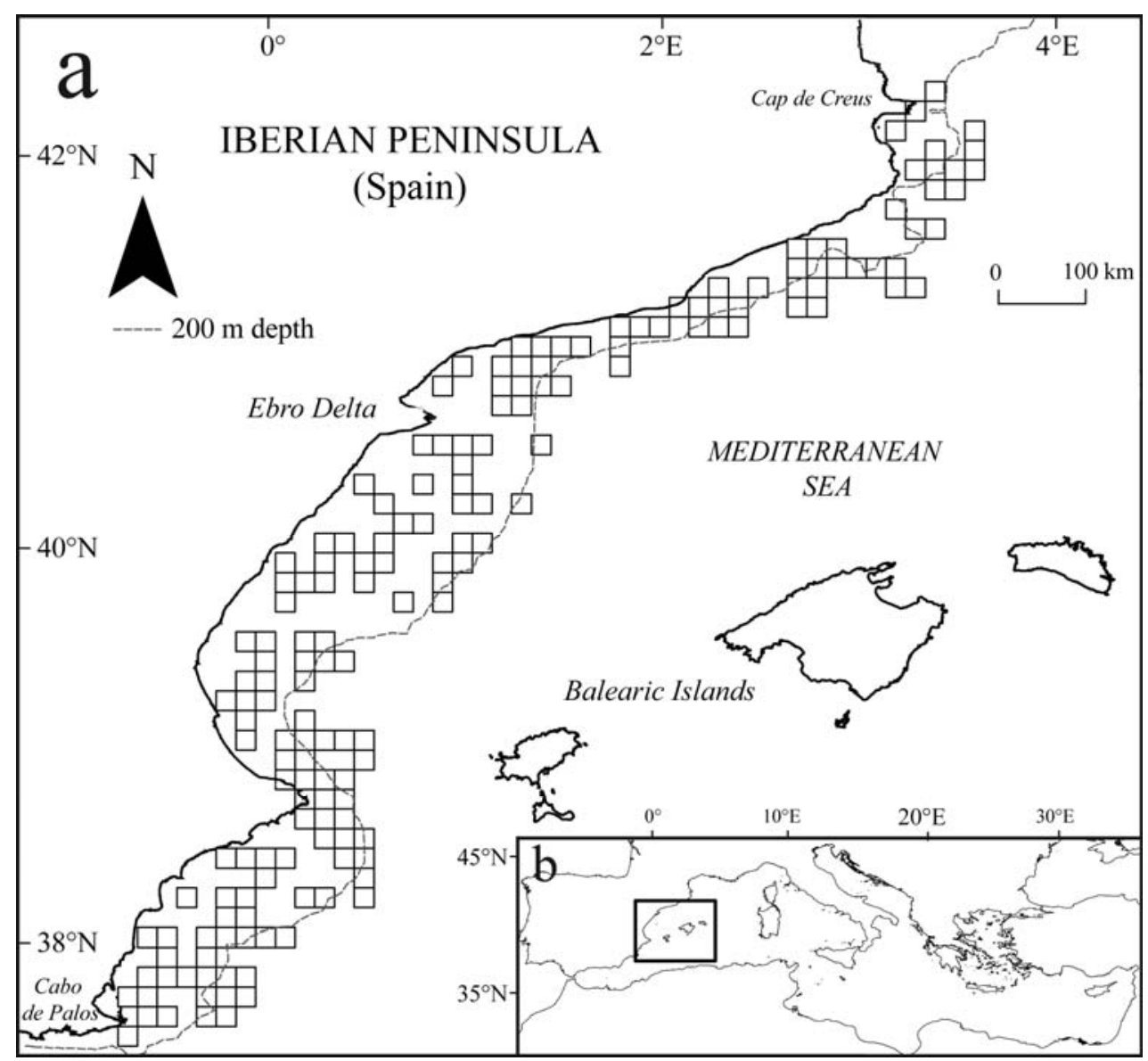


Figure 2. Spatial distribution of the observed and modelled abundance (ind $\left.\cdot \mathrm{km}^{-2}\right)$, biomass $\left(\mathrm{kg} \cdot \mathrm{km}^{-2}\right)$ and occurrence rate of small-spotted catshark Scyliorhinus canicula in the Western Mediterranean Sea.

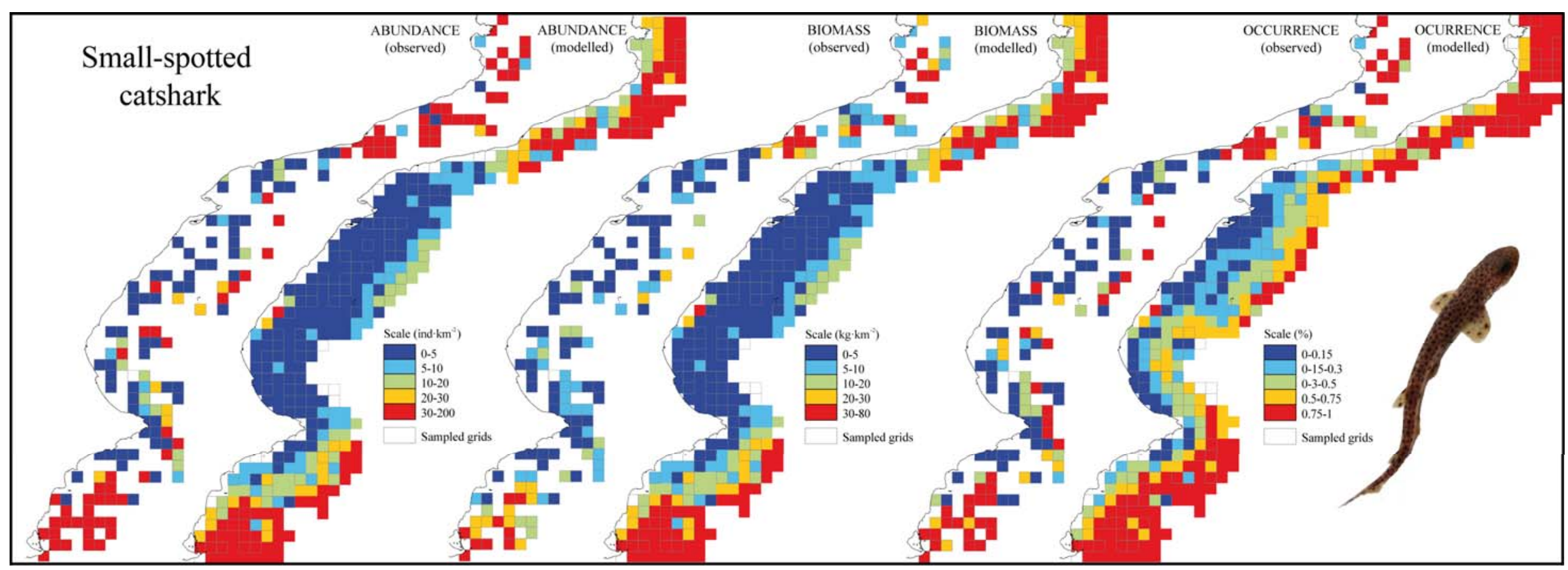


Figure 3. Spatial distribution of the observed and modelled abundance (ind $\left.\cdot \mathrm{km}^{-2}\right)$, biomass $\left(\mathrm{kg} \cdot \mathrm{km}^{-2}\right)$ and occurrence rate of Mediterranean starry ray Raja asterias in the Western Mediterranean Sea.

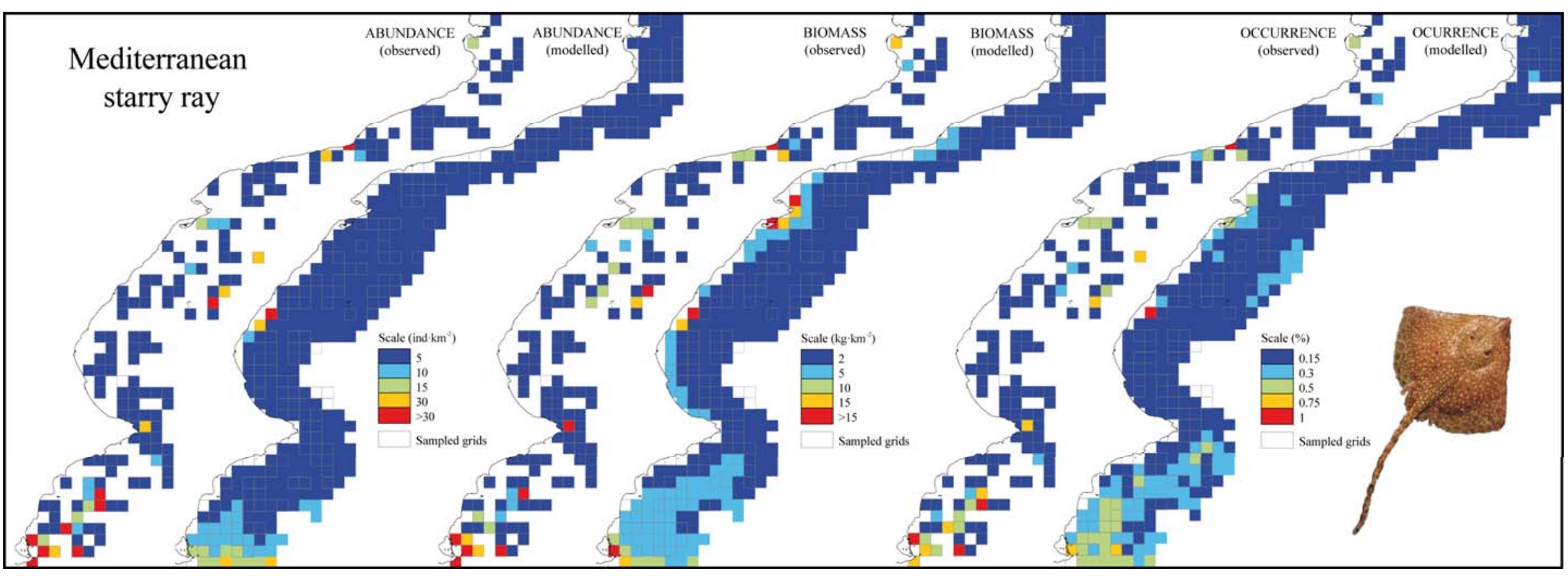


Figure 4. Pure and joint contribution to total deviance explained (\%) of environment (ENV), prey availability (PREY) and human variables (HUM) on the abundance, biomass and occurrence rate of small-spotted catshark Scyliorhinus canicula and Mediterranean starry ray Raja asterias in the Western Mediterranean Sea.

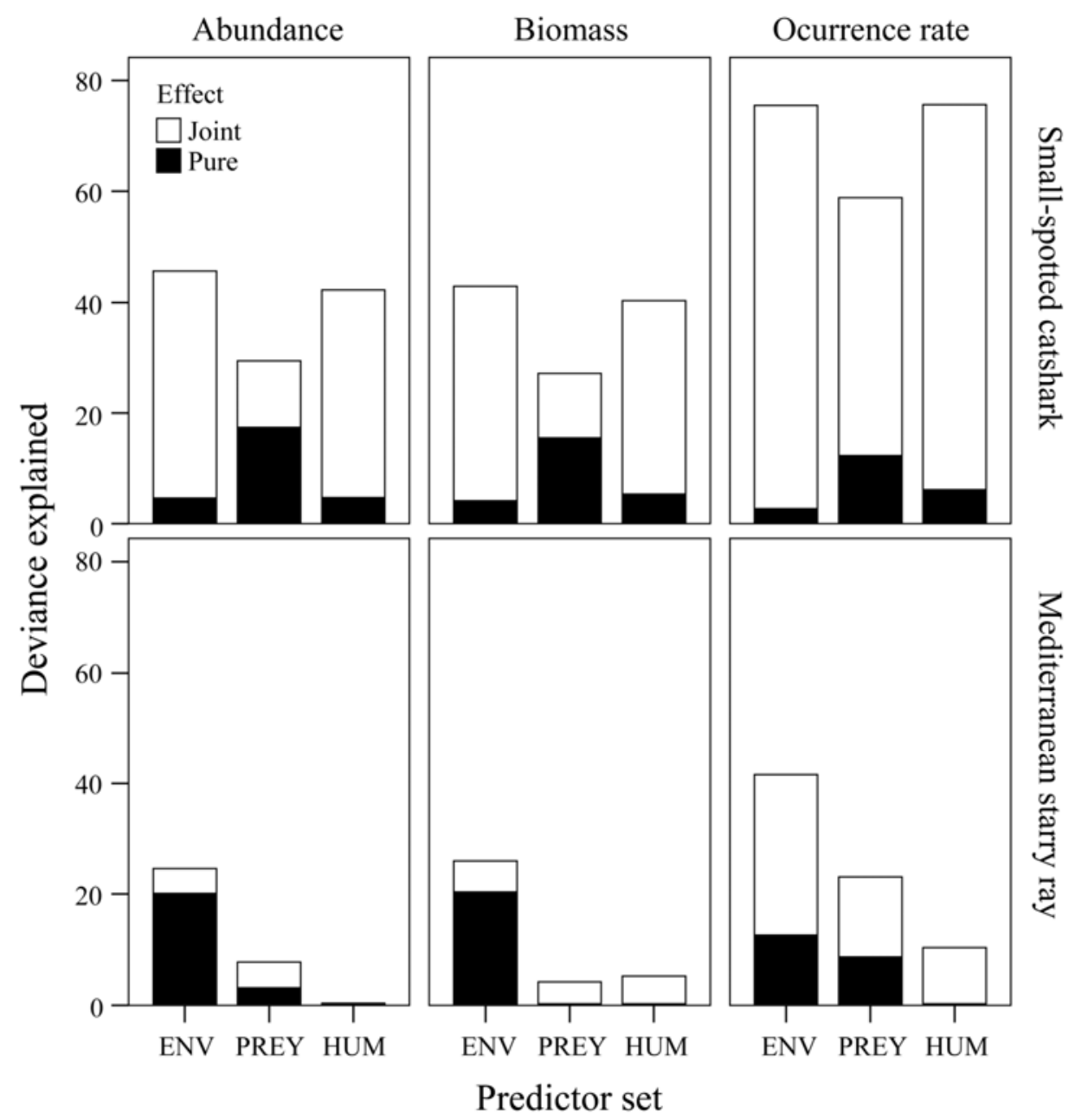

